\begin{tabular}{|c|c|c|}
\hline & Int.J.Curr.Microbiol.App.Sci (2021) 10(06): 72-81 & \\
\hline & $\begin{array}{l}\text { International Journal of Current Microbiology and Applied Sciences } \\
\text { ISSN: 2319-7706 Volume } 10 \text { Number } 06 \text { (2021) } \\
\text { Journal homepage: http://www.ijcmas.com }\end{array}$ & 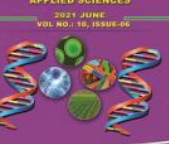 \\
\hline $\begin{array}{l}\text { EXCELLENT } \\
\text { PUBLISHERS }\end{array}$ & & inwe, jemas. \\
\hline
\end{tabular}

Original Research Article

https://doi.org/10.20546/ijcmas.2021.1006.007

\title{
Reducing Migration by Livelihoods in the PMKSY Watersheds of Andhra Pradesh's Kurnool District
}

\author{
P. V. R. M. Reddy, B. V. Ramana Kumar and R. Jhansi Rani* \\ M/s. Remote Sensing Instruments, Plot No.7, Type-I, Industrial Estate, Kukatpally, \\ Hyderabad, India \\ *Corresponding author
}

\section{A B S T R A C T}

\section{Keywords}

Migration, Poverty

Eradication,

Poverty Alleviation

Programmes,

Gender, and

PMKSY

Article Info

Accepted:

12 May 2021

Available Online:

10 June 2021
Migration is an unending story in the lives of people from the drought hit regions like Kurnool of Rayalaseema in Andhra Pradesh. There are continuous efforts from the government to mitigate migration through various policy interventions and watershed development programme is one among them. Though watershed programme initially focused on soil and water conservation activities, later it added other aspects of rural development such as biological and socio-economic based activities. These were addressed through holistic approach where small and marginal famers given priority in the soil and water conservation activities, special provisions provided in the watershed activities for socially backward sections of the society such as SC/STs, and also given priority in the livelihood's improvement activities. Kurnool district is one of the districts showed results towards reduction in migration.

\section{Introduction}

Migration in India is a complex phenomenon which has been shaped by a combination of factors and its patters and the outcomes vary between locations. The southern state of Andhra Pradesh figures prominently among the Indian states with high rate of migration from the countryside. Migration from rural AP has in fact peaked over the last 20 years due to successive drought periods. This led many people to migrate to urban areas for employment. According to UN migration defined as a move from one migration defining area to another, usually crossing administrative boundaries made during a given migration interval and involving a change of residence (Lusome and Bhagat 2006).

Until 1951, district was the migration defining area (MDA), implying that a person was considered a migrant in India only if he or she has changed residence from the district of 
birth to another district or a state. Since 1961, data on migration have been collected by considering each revenue village or urban settlement as a separate unit. A person is considered as a migrant if birthplace is different from place of enumeration.

The obvious reasons for migration in India are pull and push factors. These are basically identified migration in terms of employment, marriage, education, shifting families, business and other purposes. Urban centers have become the source points for survival for poor, unemployed, and marginalized sections of the society (Lusome and Bhagat, 2006). Most of the migration driven by distress from rural to urban is seasonal and temporary (Keshri, Kunal, and Ram B. Bhagat 2010). Gender differences are also constituting as the key elements to understand the processes of migration in terms of wage, age and other social dimensions (Garikipati, Supriya. 2008); (De Haan, Arjan. 2011). Migration patterns in the state of Andhra Pradesh has been indicating that rural distress is the cause especially in terms of livelihood and employment. The official surveys are not fully capturing the migration patterns especially at the seasonal streams, induced factors, determinants, its impacts and effectiveness of policy interventions. A study in the same region shows that the reasons for desertification of agricultural lands and emphasized on the proper irrigation planning and policy (Kumar, et al., 2019).

Poverty alleviation programmes have been made significant changes in reducing migration through various policy interventions in applying multi-fold strategy (Dev, et al., 2002). This can be understood from the Integrated Watershed Management Programme, its development activities and their prominence in the drought hit regions like Rayalaseema of Andhra Pradesh. Watershed management programs played a crucial role in reducing migration from rural to urban through various farm based and livelihood-based activities. Kurnool district depicts itself as a classical example of successive experiment in reducing migration by providing employment and income sources in more sustainable manner.

In this context, the study of Kurnool district brings out the complex dynamics of labor mobility, details of effective watershed development activities and it also shows the policy implications for reduction in migration.

Empirical evidence indicates that the results of a comprehensive study of inter-state and intrastate migration from a low to high migration from the villages of Andhra Pradesh to other areas.

The research study also highlights on how migration evolves over time and its impact on the household economy of various sections of the society. This evidence particularly highlights on;

Migration for manual work is an important livelihood option for people in rural, notably in semi-arid, relatively remote and agriculturally underdeveloped areas especially like Kurnool district.

IWMP stood as an example of generation of employment for the rural mass.

Watershed support initiatives need to be mainstreamed more towards poverty reduction strategies.

Initiatives of Integrated Watershed Management program to support to reduce the migrants can be taken up in more rigorous manner from the emerging policy framework in India.

Priorities have to be identified by the ongoing watershed support initiatives like natural 
resource management activities and these are including soil and moisture conservation works which is mostly a manual work.

The objective of the study is to understand the correlation between the reduced migrations through the livelihood activities under the watershed programme in Kurnool district.

\section{Materials and Methods}

The study conducted through the collection of secondary data at Kurnool, watershed programme and analyzed the man days generated under the watershed for various batches and releases against the funds under the livelihood activities.

\section{The Study Area}

The research study covered in Kurnool district from Batch-I to IV projects and the details comprised as the total number of projects for four Batches is 59 in 59 mandals of 243 micro-watersheds. The total number of habitations is 365 in 243 gram panchayats with 2,443 watershed user groups. Total number of projects in Batch $I$ is 13 in 71 micro-watersheds of 13 mandals. 99 are the total number of habitations in 60 gram panchayats with 374 user groups. For Batch II, the total projects are 16 in 64 microwatersheds of 16 mandals. Total number of habitations is 98 in 72 gram panchayats with 553 user groups. Under Batch III, total numbers of projects are 22 for 76 microwatersheds of 22 mandals. 81 are the total number of gram panchayats in consisting of 121 habitations with 1,456 user groups. For Batch IV, total number of projects is 8 with 32 micro-watersheds of 8 mandals. Total number of habitations is 47 in 30 gram panchayats with 60 user groups.

The IWMP was implemented following the guidelines issued. Bio-physical and biological interventions are made to conserve resources and increase biodiversity. Alternative livelihood action plans were planned and implemented to provide additional income to land less and vulnerable groups. The impacts of these measures were analyzed at microwatershed wise and summarized for the project as a whole and compiled for the district.

\section{Data Analysis and Tabulation}

The works of watershed comprising as NRM, PSI, EPA, and Livelihoods for Batch-I to IV of Kurnool for 8 projects were tabulated and analyzed works and man-days wise.

The primary household data analyzed on migration, agricultural and off-farm income sources before and after the project intervention.

Focus Group Discussions (FGDs) were conducted and recorded about the impact of the watershed project on employment creation and reduction in migration.

\section{Initiation of Watershed Programme, Objective, Coverage}

The Department of Land Resources (DoLR), Ministry of Rural Development (MoRD) has been implementing the Integrated Watershed Management Programme (IWMP) since 2009. The PMKSY is expected to treat 25 million ha during XII Plan period (2012-13 to 2016-17). Based on regional classification, the treatment costs are Rs. 12000 or Rs. 15000 per hectare and shared as 90:10 between the Government of India and implementing states.

The main objective of IWMP is to ensure sustainable livelihoods with the major indicators like improving incomes not only at household level but also at individual through watershed activities which can bring positive outcomes. The rational for this objective is that the need of securing livelihoods of small, 
marginal, and asset-less in terms of food and income security since the programme designed so diverse and more inclusive in nature by given magnitude of expenditure and possible outcomes from the previous programmes like DPAP and DDP. The integrated approach has a multiplicity of interrelated sectors from natural resource management, production systems and livelihoods for the asset-less along with supporting structures such as capacity and institution building, monitoring and evaluation, and convergence.

Initiation of Integrated Watershed Management Programme (IWMP) intended to restore ecological balance by conserving natural resources through preventing soil-run off, regeneration of vegetative cover, construction of water harvesting structures, and re-charge of ground water. This programme mainly focused on semi-arid regions in the country and some areas were selected as priority based where the programme saw potential in improving farm based and non- farm-based activities.

This programme enabled communities that have depended upon not only at natural resource management, productivity-based activities but also livelihoods by creating assets through capacity building and generating the employment. The programme also viewed as effective tool for food security and sustainable development of the communities in enduring employment through improving livelihoods. This is the demanddriven programme where targets were set, and activities carried out to achieve them. It varies from context to context, place to place but the integrated model largely applied to meet the objectives set by IWMP. With this aim, IWMP implemented in one of the well-known areas of drought-prone and semi-arid region called Rayalaseema of Andhra Pradesh.

\section{Watershed Programmes in Kurnool District}

The successful watersheds from the Kurnool district of Andhra Pradesh have taken to assess the potential of watershed programmes in in enhancing rural livelihoods, preventing, and reducing migration from rural to urban areas. Kurnool district has a long history of migration not only to the near districts but to the other states and countries especially Saudi Arabian countries. This district is known for drought and heavy migration. It is, therefore, essential to develop these areas by adopting appropriate soil and water conservation measures on watershed basis for reducing environmental impacts of droughts. Due to large number of water conservation and water harvesting structures taken up in the dist. during 1993-95, 1000 m.cum of additional groundwater recharge was made possible which is very encouraging and forms a base for evolving a comprehensive watershed development. IWMP has the reputation in claiming the success of Kurnool district in regarding to the improvement of livelihoods, water and soil conservation works, and productivity-based activities through entry point activities and institution \& capacity building.

There are series of watershed management works from batch-wise have been happening from 2009-10 to 2019-20. These have implemented with an objective of conserve, improve efficacy and management of Natural Resources through people's active participation and administrative institutions. The works comprised as land development, soil conservation works, water harvesting works, afforestation works, horticulture and livestock works. Likewise, Productive Support Improvements (PSI) activities, Entry Point Activities and Livelihood activities are also contributed immensely in creating employment. These are the major works 
which have generated employment for the rural mass directly addressed and helped in reduction of migration.

\section{Various Works Implemented under Watershed Programme}

The Entry Point Activities (EPA), Productive Support Improvements (PSI), Natural Resource Management (NRM) and Livelihood (LH) are the major works carried under watershed for holistic development. The convergence strategy is developed for treating the catchment on saturation basis using NREGS funds by taking wage intensive works by NREGS funds and material intensive works like Drainage line treatment works, Ground water Recharge works, Afforestation, fodder development works with IWMP fund in WCCs. Necessary Software is deployed in both MCC \&WCC as per the convergence strategy to avoid duplication.

The livelihood (LH) activities in on farm and off farm livelihood interventions are taken up in convergence with SERP using 9\% of project funds by preparation of household action plans. The funds are released to the Village Organizations through SERP(Society Elimination of Rural Poverty). The livelihood activities like dairy, small ruminants, petty business etc are take up through Village Organizations.

\section{Importance of Livelihoods Works in Employment Generation}

Prevention of migration in generating employment under watershed project areas have happened through various activities taken up based on the priority since Batch I to IV. Generation of employment can be seen in the form of increasing in man-days through the activities provided. These can also mark form all the activities provided under major components. Among these, apart from all the major components Livelihoods also played key role and contributed significantly.

The total percentage of expenditure under Livelihoods from the total watershed fund allocation is $9 \%$. Livelihood component has a direct benefit in providing financial assistance to the activities taken up. These activities can be seen in setting up provision shop, petty businesses, goat/sheep rearing, cattle rearing, grinding machine, saree business, bags business, stitching machine and so on. Allocation of $9 \%$ of the total watershed project fund varies from one to the other batch. Until now, there are four Batches of watershed projects implemented and its details tells us that improvements in not only developing the areas based on the soil and water conservation activities but also people's socio-economic development which is crucial for any sort of developmental activities.

In the case of Kurnool district of Rayalaseema region the total fund facilitated for livelihood component from Batch I - 608 (lakhs), Batch II - 679 (lakhs), Batch III - 913(lakhs) and Batch IV - 361(lakhs) and the total amount of all the Batches is 2,561 (lakhs).

The table is also showing the Person-days generated under various components such as IWMP and EGS also among SC and ST communities including others from the watershed projects per Batch-wise. For IWMP, the details containing is 2,10,150 in Batch-I, 1,84,622 in Batch-II, 2,19,253 in Batch-III, 65,806 in Batch-IV and the total financial amount is $6,79,831$ man-days generated under IWMP.

Problem of migration has been appearing in various policy objectives and perspectives. Usually, the attention tends to focus on reducing the numbers of migrants in each programme or project area. For example, rural development programmes and the social 
protection schemes including the National Rural Employment Guarantee Act (NREGA) and watershed development programmes earlier have often included an objective to reduce the numbers of out-migrants, and the emerging evidence from studies suggests on to decrease the distress migration from villages among workers rather than bearing the social and other costs of migrating elsewhere in search of work. Under EGS, the total number of person-days generated is 57,11,393 and $8,37,033$ in Batch-I, 12,93,840 in Batch-II, $26,13,813$, in Batch-III, and 9,66,707 in Batch-IV under EGS program and similarly Under IWMP totally covered 679,831 man days from Batch-I to Batch-IV projects.

Employment generation is also significant among SC/STs in watershed projects apart from others caste communities. Each project villages have composition of General, OBC, SC, ST and other sub-caste communities. Total number of person-days generated for SCs is $13,63,458$ and in Batch-I is 1,87,096, 3,00,162 in Batch-II, 6,42,023 in Batch-III and 2,34,277 is for Batch-IV. From this, the total beneficiaries belong to SCs denoting that the total number of beneficiaries 6,021 and during Batch-I is 1,429, Batch-II is 1,723 and for Batch-III is 2,326 and 543 in Batch-IV.

Among STs, the total number of person-days created are 89,045 and during Batch $I$ is 34,660 , in Batch II is $2,834,48,856$ for Batch III and in batch IV is 2,695. The total beneficiaries for ST communities are 891 and during Batch I 338, Batch II is 69, for Batch III is 477 and in Batch IV is 7.

Along with these communities, the other communities also showed remarkable change from Batch I to IV. The total number of person-days generated in other caste communities is 49,44,658 and during Batch I is $8,32,403$, Batch II is $11,73,965$, for Batch III is 21,42,759 and 7,95,531 in Batch IV. The total beneficiaries for Other Caste communities are 29,755 and during Batch I 6,481 , Batch II is 8,740 , for Batch III is 11,438 and in Batch IV is 3,096.

\section{Status of Migration in Kurnool District}

Before assessing the impact of drought and mitigation through the watershed intervention, it is essential to know about the biological and geographical features of the Kurnool District, which is experiencing drought consistently and the causes of drought in that particular area. The district which falls in the rain shadow area of Western Ghats and in the interior of Deccan Plateau, is the one of the chronically drought affected district in the country. The Kurnool district lies in the northern part of the state of Andhra Pradesh between latitude $14^{0} 54^{\prime} \mathrm{N}$ to $16^{0} 18^{\prime} \mathrm{N}$ and longitudes $76^{0} 58^{\prime} \mathrm{E}$ to $79^{0} 34^{\prime} \mathrm{E}$ at an average altitude of about $128 \mathrm{~m}$ from sea level. Trends of desertification are also seen in parts of the district. Groundwater levels are alarmingly low and receding fast. Further degeneration of existing marginal and degraded forests is happening in the last four decades and acute scarcity of drinking water, fodder and fuel is occurring in every alternate year which is a serious concern. All these factors are creating tremendous concern and awareness regarding the danger that is looming large among the masses of the district and it has unique identity with respect to crop failure, depletion of ground water, indebtedness, migration, and suicides. Watershed management programmes have come to the fore to address all the pertinent issues in specific to the district.

Kurnool is one such district of AP where drought conditions have been occurring consistently over the past so many years causing severe stress to the local economy, especially the agriculture. An analysis of rainfall data for the past decades reveals that in every decade almost 7 years are prone to 
drought. In the present decade almost six years were rainfall deficient years resulting in severe drought conditions. Kurnool is now declared as hot-arid district and the Desert Development Programme (DDP) through watershed development programme is in implementation. Almost all the national schemes mentioned above are implemented in AP. To address the 'drought', several longterm and short-term programmes for the rural India have evolved. Some of them are follows as:

National Watershed Development Programme for Rain fed Areas (NWDPRA)

Integrated Watershed Development (IWDP)

Drought Prone Areas Programme (DPAP)

Desert Development Programme (DDP)

Accelerated Rural Water Supply Programme (ARWSP)

Pradhan Mantri Gramodaya Yojana (PMGY)

Food for Work Programme (FWP)

Rural Employment Guarantee Programme (REGP)

Integrated Wasteland Development Programme (IWDP)

Swarna-Jayanthi Grameen Rozgar Yojana (SGRY)

Swama-jayanthi Grameen Swarozgar Yojana (SGSY)

Tube wells, Food \&Fodder development Programmes etc.,

Under different Ministries /Departments of the Central Government and the State Governments.
The persistent drought condition in the district collapsed the labor market especially, farm and off-farm based activities which are forced the laborers and the fanners to migrate. Most of them are migrated to Bangalore, Tamil Nadu, Hyderabad, Telangana, Mumbai, and other countries like Saudi Arabia for livelihoods during the drought periods. They are engaged and occupied in constructionbased activities, poultry farms, sanitation, store keeping, cable works and rag picking. However, some of them have come back and settled in the villages because of watershed development programmes which have introduced the 'drought relief works' and wage employment.

\section{Impact of Migration on Rural Poor}

The impact of migration was basically on the farmers of all economic classes such as large, medium, small, and marginal farmers and landless laborers. Due to lack of sufficient groundwater and erratic power supply, most of the farmers here started cultivating irrigable dry (ID) crops (groundnut, sun flowers and ragi). But the unavailability of sufficient groundnut seeds posed another problem in every season. Moisture stress in groundnut crops and pest in groundnut added to their woes. Also, many of the villages showed decline in the yield of dry fodder compelled almost all farmers to sell their cattle or reduce the size of the cattle. All these are leading migrate to other places for works. In the case of landless agricultural labour, the place showed more out migration to other places since they have not many choices left to sustain other than migrate.

This led more people left homes and migrated to nearby and faraway places to lead lives with minimum livelihood options. Out migration also not sufficient for their needs to lead better life since most of them are unskilled and depended on agriculture and allied sectors but 
not service and primary sectors much. This denotes the socio-economic background of the place in a given geo-physical conditions. Migration patterns in the district of Kurnool does not have one way to explain but it is multidimensional which has a lot to explain about nature of the land, air, water, resources, and people. This seems to be nobody can help it but not so in reality since changes can happen with the efforts in making places to work for people and at the same time people also work for making places. It is a two-way process which reminds us that humans and the nature relationship.

\section{Governance of Programmes Played Key Role in Generating Employment}

The NREGS and IWMP both are the very key important programmes played a key role in employment generation and helped in reduction of migration in rural areas. The MGNREGS Act aims at enhancing the livelihood security of people in rural areas by guaranteeing hundred days of wageemployment in a financial year to a rural household whose adult members volunteer to do unskilled manual work. This is one of the successful programmes have generated employment for the rural poor which was launched at Bandlapalli village under Narpala mandal in Anantapur District of Andhra Pradesh on $2^{\text {nd }}$ February 2006.

The NREGS have been tremendous efforts put by central and state governments to address the poverty, development, and inequality across the regions. The main objectives of these programmes are to eradicate poverty, uplift them towards development by empowering and bring sustenance. Similarly, watershed also played a key role in generating the employment by conserving natural resources in rural areas.

\section{Results and Discussion}

The relationship between watershed activities of NRM, PSI, EPA, \& Livelihoods and migration pattern is inter-connected well and important to see various dimensions pertaining to the unprecedented problems of poverty, drought, water scarcity and migration. This also explains reasons for how and why only certain regions have heavy migration that too from certain caste communities but not others.

Watershed programmes in India general and Rayalaseema of Andhra Pradesh in particular have explanations for unanswered questions. Projects in Kurnool district of Andhra Pradesh from Batch I to IV (2009-20) have shown improvements in not only farm-based activities but also the human development. This was possible due to effective implementation of watershed activities with people's active participation, especially through provision of Livelihoods and other activities. The details were presented in the analysis part of the income generated throughout the programmes in Kurnool district.

The watershed development aims to increase employment through labor intensive soil and water conservation and providing livelihoods. The watershed programmes succeed by reducing the flow of migration. Also provided increase in short-term employment as well as long-term productivity gains. 
Table.1 Project wise Details of Watershed Programmes in Kurnool District from Batch-I to IV

\begin{tabular}{|c|c|c|c|c|c|c|}
\hline S. No & Name of the Batch & Batch-I & Batch-II & Batch-III & Batch-IV & Total \\
\hline $\mathbf{1}$ & Total No. of Mandals & 13 & 16 & 22 & 8 & 59 \\
\hline $\mathbf{2}$ & Total No. of Projects & 13 & 16 & 22 & 8 & 59 \\
\hline $\mathbf{3}$ & $\begin{array}{c}\text { Total No. of Micro } \\
\text { Watersheds }\end{array}$ & 71 & 64 & 76 & 32 & 243 \\
\hline $\mathbf{4}$ & $\begin{array}{c}\text { Total No. of Gram } \\
\text { Panchayats }\end{array}$ & 60 & 72 & 81 & 30 & 243 \\
\hline $\mathbf{5}$ & $\begin{array}{c}\text { Total No. of } \\
\text { Habitations }\end{array}$ & 99 & 98 & 121 & 47 & 365 \\
\hline $\mathbf{6}$ & $\begin{array}{c}\text { Total No. of } \\
\text { Watershed User } \\
\text { Groups }\end{array}$ & 374 & 553 & 1,456 & 60 & 2,443 \\
\hline
\end{tabular}

Table.2 Kurnool-Batch-I to IV 2009-20 Watershed Works for Livelihoods (Lakhs)

\begin{tabular}{|c|c|c|c|c|c|c|c|}
\hline S. No & Name of the Batch & Subject & Batch-I & Batch-II & Batch-III & $\begin{array}{l}\text { Batch- } \\
\text { IV }\end{array}$ & Total \\
\hline 1 & $\begin{array}{l}\text { Expenditure under } \\
\text { Livelihoods }(9 \%)\end{array}$ & Lakhs & 608 & 679 & 913 & 361 & 2,561 \\
\hline \multirow[t]{6}{*}{2} & \multicolumn{7}{|c|}{ Person-days generated under } \\
\hline & a. IWMP & No & 210,150 & 184,622 & 219,253 & 65,806 & 679,831 \\
\hline & b. EGS & No & 837,033 & $1,293,840$ & $2,613,813$ & 966,707 & $5,711,393$ \\
\hline & c. SCs & No & 187,096 & 300,162 & 642,023 & 234,177 & $1,363,458$ \\
\hline & d. STs & No & 34,660 & 2,834 & 48,856 & 2,695 & 89,045 \\
\hline & e. Others & No & 832,403 & $1,173,965$ & $2,142,759$ & 795,531 & $4,944,658$ \\
\hline \multirow[t]{4}{*}{3} & $\begin{array}{c}\text { No. of beneficiaries } \\
\text { benefited }\end{array}$ & No & 8,248 & 10,528 & 14,222 & 3,646 & 36,644 \\
\hline & $\begin{array}{c}\text { No. of SC } \\
\text { beneficiaries }\end{array}$ & No & 1,429 & 1,723 & 2,326 & 543 & 6,021 \\
\hline & ST beneficiaries & No & 338 & 69 & 477 & 7 & 891 \\
\hline & Other beneficiaries & No & 6,481 & 8,740 & 11,438 & 3,096 & 29,755 \\
\hline
\end{tabular}

The evidence indicates that watershed programme succeeds in reducing migration rates at least during the implementation phases of Batch I to IV (Phase-wise) for the project period. It is also found that employment opportunities have been increased and migration gradually reduced at a larger extent especially among people who depend on labor and livelihoods activities in the selected watershed project villages.
Also, employment days increased in landbased activities and livelihoods in the watershed project villages.

The wage rates have increased and resulting in higher incomes due to facilitating the works and making them to participate and produce. This can be observed even in NRM and PSI activities. Because of higher yields, the income of the farmers also increased. The livelihoods activities facilitate so many to 
equip themselves in using the provided activities. This is largely played at building confidence and capacity in them which turned out as self-sustenance.

The significant feature in these projects is accommodating SC/STs in the income generating activities along with EGS activities.

This provided more days of person works and employment which further led to higher income. Why this is important to understand is most of the migrant workers belong to SC/STs.

So, with providing employment to them directly and indirectly is helping them not to leave the native place for work to other places.

This is a sea change occurred due to effective implementation of watershed projects from Batch I to IV.

This also provided other beneficiaries in the project villages in creating employment which is also telling us that benefiting other caste communities as well.

So, this denotes that the watershed activities have been contributing for the overall development of project villages in all spheres. Overall, it is found that Batch-I to IV, Kurnool watershed projects generated employment among the needy which is crucial for everyday sustenance of various income groups.

\section{References}

De Haan, Arjan. Inclusive Growth?: Labour Migration and Poverty in India. International Institute of Social Studies, 2011.

Dev, S. Mahendra, and P. Padmanabha Rao. "Poverty Alleviation Programmes in Andhra Pradesh: An Assessment." Hyderabad: Centre for Economic and Social Studies (2002).

Garikipati, Supriya. "Agricultural wage work, seasonal migration and the widening gender gap: Evidence from a semi-arid region of Andhra Pradesh." The European Journal of Development Research 20, no. 4 (2008): 629-648. In Annual conference of Indian Association for the Study of Population (IASP) during, vol. 7, p.

Keshri, Kunal, and Ram Bilash Bhagat. "Temporary and seasonal migration in India." Genus 66, no. 3 (2010): 25-45.

Kumar, B. Pradeep, K. Raghu Babu, M. Rajasekhar, and M. Ramachandra. "Assessment of land degradation and desertification due to migration of sand and sand dunes in Beluguppa Mandal of Ananthapuramu district (AP, India), using remote sensing and GIS techniques." J. Ind. Geophys. Union (March 2019) 23, no. 2 (2019): 173180.

Lusome, R., and R. Bhagat. "Trends and patterns of internal migration in India, 1971-2001."Rout, Sanjit. "Drought in Ananthapuramu District: An Overview.

\section{How to cite this article:}

Reddy, P. V. R. M., B. V. Ramana Kumar and Jhansi Rani, R. 2021. Reducing Migration by Livelihoods in the PMKSY Watersheds of Andhra Pradesh's Kurnool District. Int.J.Curr.Microbiol.App.Sci. 10(06): 72-81. doi: https://doi.org/10.20546/ijcmas.2021.1006.007 